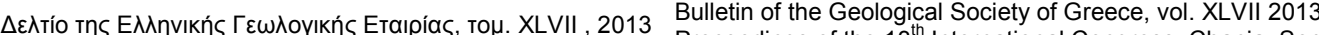
X

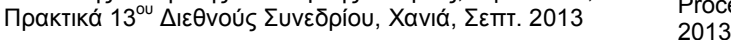

\title{
?KIMMERIDGIAN-TITHONIAN SHALLOW-WATER PLATFORM CLASTS FROM MASS FLOWS ON TOP OF THE VARDAR/AXIOS OPHIOLITES
}

\author{
Kostaki G. ${ }^{1}$, Kilias A. ${ }^{1}$, Gawlick H. J. ${ }^{2}$ and Schlagintweit F. ${ }^{3}$ \\ ${ }^{I}$ Aristotle University of Thessaloniki, School of Geology, Department of Geology, \\ gkostaki@geo.auth.gr,kilias@geo.auth.gr \\ ${ }^{2}$ University of Leoben, Department Applied Geosciences and Geophysics, Chair of Petroleum \\ Geology,Hans-Juergen.Gawlick@unileoben.ac.at \\ ${ }^{3}$ Lerchenauer Str. 167, 80935 München, Germany,Felix.Schlagintweit@gmx.de
}

\begin{abstract}
The Late Jurassic to Early Cretaceous sedimentary succession of the Neochorouda Unit lies unconformably on top of the Oreokastro ophiolites of the Vardar/Axios "suture zone" in northern Greece. This succession consists of turbidites and mass flows and provides an upper limit for ophiolite emplacement. New biostratigraphic and microfacies analysis from the clasts in the mass flows were carried out for a better understanding of the Late Jurassic to Early Cretaceous geodynamic history. Microfacies and organism content prove the onset of Late Jurassic carbonate platforms on top of a Middle to Late Jurassic nappe stack striking from the Eastern Alps to the Hellenides.

Middle to Late Jurassic nappe stacking towards WNW to NW followed late Early to Middle Jurassic intra-oceanic thrusting in the Western Vardar/Axios (= Neotethys) Ocean and subsequent ophiolite obduction onto the Pelagonian Units forming a thin-skinned orogen on the lower plate. After ophiolite emplacement KimmeridgianTithonian carbonate platforms sealed widespread this tectonic event. Tithonian extension due to mountain uplift resulted in partial erosion of these platforms and new extensional basins were formed. Late Tithonian to earliest Cretaceous erosion of the uplifted nappe stack including the obducted ophiolites resulted in sediment supply into the newly formed basins also east of the Pelagonian Units.
\end{abstract}

Key words: Neotethys, Tectonics, Stratigraphy.

\section{Пєрí $\eta \psi \eta$}

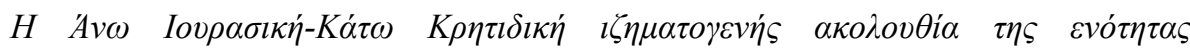

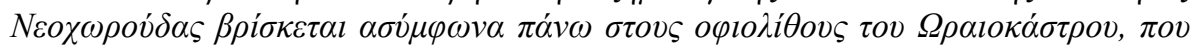

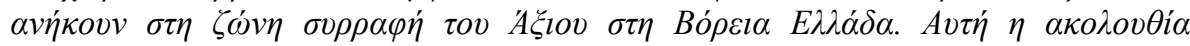

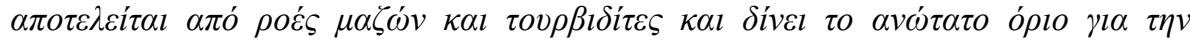

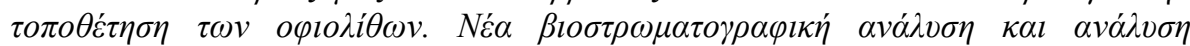

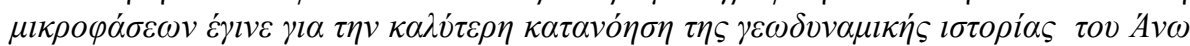

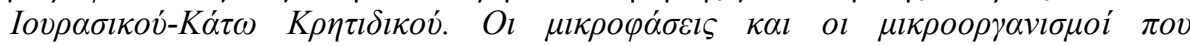

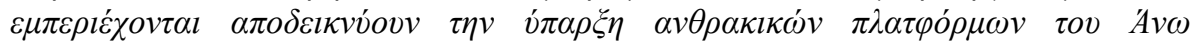




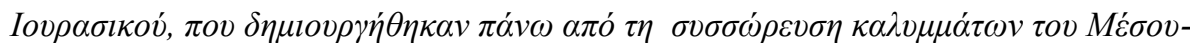
Av

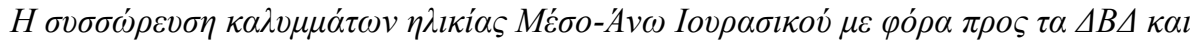

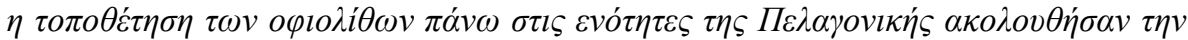

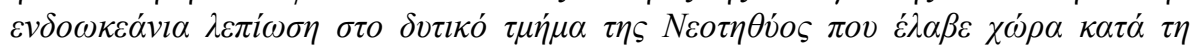

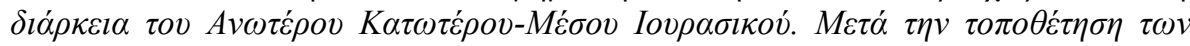

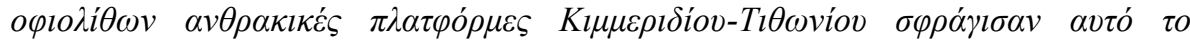

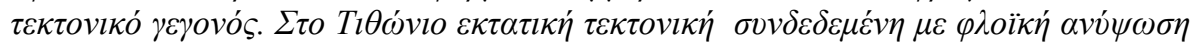

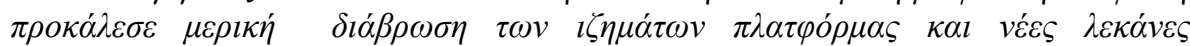

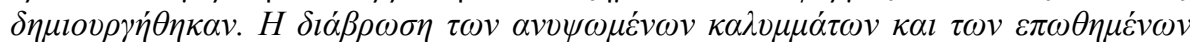

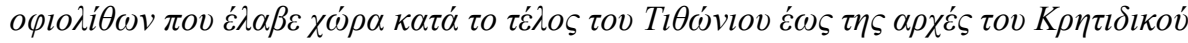

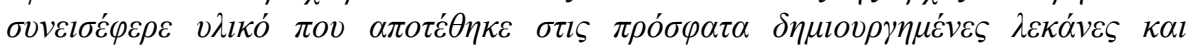

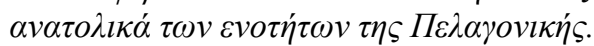

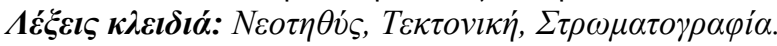

\section{Introduction and Geological Overview}

The Vardar/Axios zone is located parallel to the Hellenide-Dinaride chain in Northern Greece, FYROM, and Serbia. Kossmat (1924) was the first who described the Vardar/Axios zone as a 30 to $70 \mathrm{~km}$ wide NNW-SSE trending belt between the Serbomacedonian massif to the east and the Pelagonian Zone (and equivalents) to the west, e.g. in Northern Greece.

The Greek part of Vardar/Axios zone has been subdivided by Mercier (1968) into three subzones according to their palaeogeographic characteristics: from west to east the Almopias, Paikon and Peonias zones. Neochorouda area, which is a material area for this study, belongs to Peonias subzone. The dominant rocks of the Peonias subzone are Mesozoic sedimentary and igneous rocks, various types of metamorphic rocks and ophiolites with associated mélanges, including the Oreokastro ophiolites. The latter together with the ophiolites of Guevguely, Thessaloniki and Chalkidiki form the Innermost Hellenic Ophiolite Belt (Bebien et al., 1986). The presence of ophiolites is of great interest for the geotectonic evolution and crucial for the still controversially discussed palaeogeographic setting of them and therefore a key for the geodynamic interpretation of the whole Hellenides.

These ophiolites represent the remnants of the Mesozoic oceanic lithosphere (Neotethys domain) within the Hellenide-Dinaride segment of the Alpine orogenic system in a north-south trending belt (Smith \& Spray, 1984; Channell \& Kozur, 1997). The formation of these ophiolites should have happened between 170-155 Ma in the back-arc region of the intra-oceanic subduction of the Meliata-Maliac (= Neotethys) Ocean that took place on the eastern border of the Vardar/Axios Ocean (e.g., Stampfli et al., 2000; Zachariadis et al., 2006). About the palaeogeographic position of the Peonias oceanic basin see also Brown \& Robertson (2003). These authors proposed that the Vardar/Axios ocean was a back arc basin (SSZ ophiolites) behind the Paikon volcanic arc (for a different view: Ricou et al., 1998; Vergely \& Mercier, 2000), which should have remained open at least until the Late Cretaceous (Robertson et al., 2012), but earlier the westward thrusting in this independent ocean basin was considered as Late Jurassic.

According to other authors the Vardar/Axios ophiolites were thrusted on top of the Pelagonian units (e.g., Roddick et al., 1979; Brown \& Robertson, 2004) around the Middle/Late Jurassic boundary caused by intra-oceanic thrusting and westward ophiolite obduction. They should therefore represent the easternmost part of a huge ophiolite nappe which derived from the Neotethys Ocean (e.g., Schmid et al., 2008; Gawlick et al., 2008; Kilias et al., 2010). According to the last two author groups the western part of the Neotethys Ocean was closed in early Late Jurassic times whereas the eastern part remained open as SSZ Vardar Ocean. 
In the study area Oreokastro ophiolites to the east are in tectonic contact with a Late Triassic-Early Late Jurassic (Dimitriadis \& Asvesta, 1993) turbiditic succession (Melissochori formation). To the west the ophiolites are overlain by a fossiliferous ?latest Jurassic to Early Cretaceous sedimentary succession (Neochorouda Unit) (Kockel et al., 1977; Meinhold et al., 2009) (Figure 1). This succession consists of mass flows which contain components of different reefal limestones of Late Jurassic age (Figures 2 and 3). These Late Jurassic shallow-water limestone clasts are of different microfacies and were detected near the village of Neochorouda.

The present paper describes the mass-flow components in the Neochorouda Unit (Figure 2) together with new biostratigraphic and microfacies data. Our results allow to reconstruct the formation of a Late Jurassic carbonate platform on top of the nappe stack of Vardar/Axios ophiolites sealing their emplacement. The results are important for the reconstruction and the timing of the thrusting processes of the Vardar/Axios ophiolites. Their emplacement can be dated as older then the creation of the shallow-water carbonates on top and therefore at least as late Middle to early Late Jurassic. The sequence of the Neochorouda Unit in the Vardar/Axios zone with the incorporated eroded components resemble identical successions known west of the Pelagonian units, e.g. in Albania or Serbia.

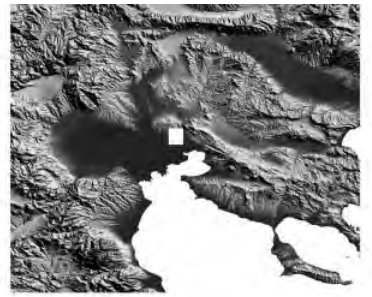

Cenozoic sediments

Phyllites with intercalations of limestone

01010 Neochorouda unit

Aspri Vrisi serie \& Chortiatis unit

Triassic limestone

Volcanosedimentary serie of Permiantriassic age

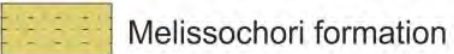

Gneiss, micaschist

Ophiolite complex
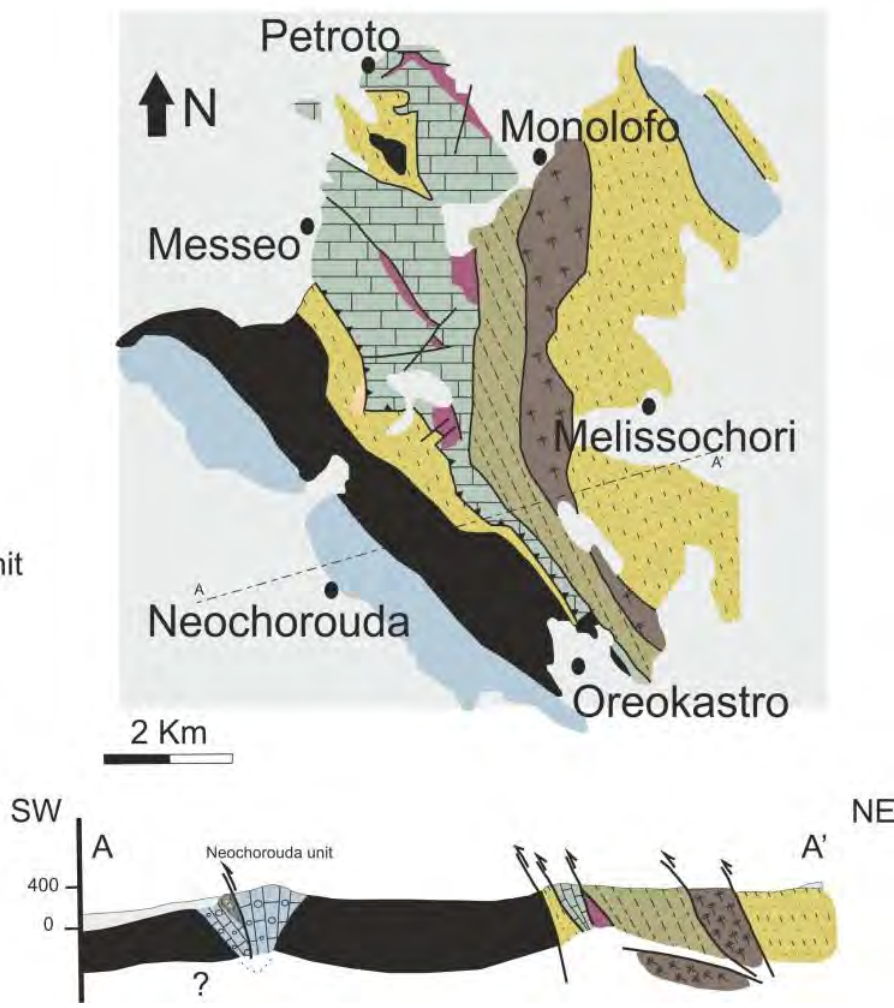

NE

Figure 1 - Geological map of Neochorouda area modified after Kockel \& Mollat (1977).

\section{Stratigraphy and Platform Reconstruction}

\subsection{Neochorouda Unit}

This succession of mass flows has a thickness of about $320 \mathrm{~m}$ and the components size ranges from a few centimetres up to half a meter (Figure 2). According to the biostratigraphic and microfacies analysis of the clasts in the mass flows we distinguish from bottom to top: 
a) A breccia of approximately $10 \mathrm{~m}$ thickness with gabbroic and few shallow-water carbonate clasts with Labyrinthina mirabilis Weynschenk and Griphoporella jurassica (Endo) (Figure 4).

b) A coarse-grained breccia of about $6 \mathrm{~m}$ thickness with mixed ophiolite material and shallowwater carbonate clasts containing besides corals and other reef builders also Neoteutloporella socialis (Praturlon), Crescentiella morronensis (Crescenti), Perturbatacrusta leini Schlagintweit \& Gawlick, Labes atramentosa Eliasova (Figure 5).

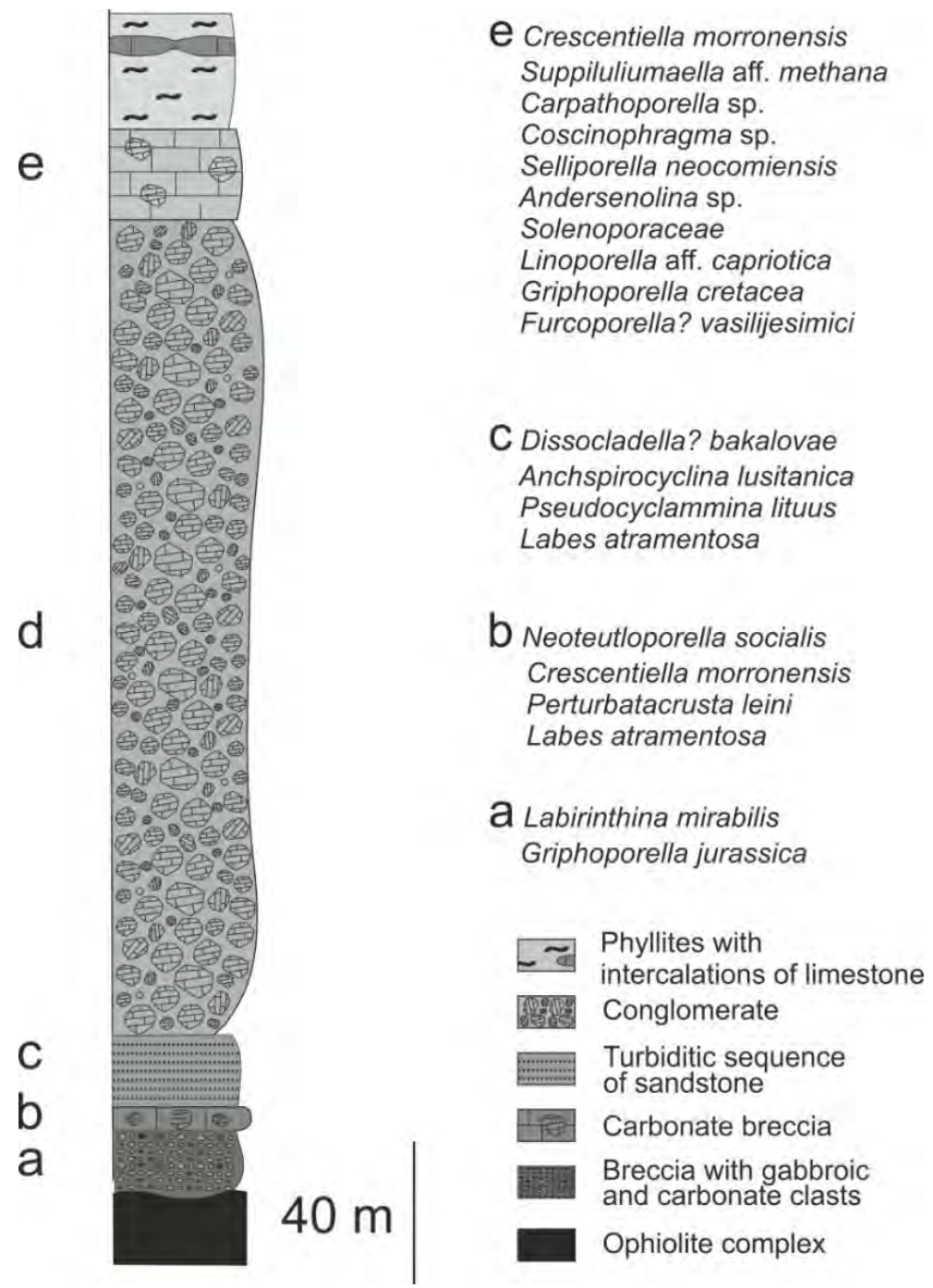

Figure 2 - Stratigraphic column of the Neochorouda Unit.

c) A 20 meters turbiditic sequence of sandstones, with some intercalated coarse-grained mass flows. This sequence contains ammonites of Berriasian age (Mussallam \& Jung, 1986). The carbonate clasts contain Dissocladella? bakalovae, Anchispirocyclina lusitanica (Egger), Pseudocyclammina lituus (Yokoyama), L. atramentosa Eliasova (Figure 6).

d) A polymictic conglomerate of approximately $250 \mathrm{~m}$ thickness with e.g. quartzite's resp. metamorphic radiolarites, different metamorphosed shallow-water clasts of most probably Middle Triassic age but without ophiolite components (Figure 7) and 
e) again shallow-water carbonates with a thickness of $30 \mathrm{~m}$ with $C$. morronensis (Crescenti), Suppiluliumaella aff. methana Dragastan \& Richter, Carpathoporella sp., Coscinophragma sp., Selliporella neocomiensis (Radoicic), Andersenolina sp., Solenoporaceae, Linoporella aff. capriotica (Oppenheim), Griphoporella cretacea (Dragastan), Furcoporella? vasilijesimici Radoicic (Figure 8). This part of the series is Berriasian to Valanginian in age.
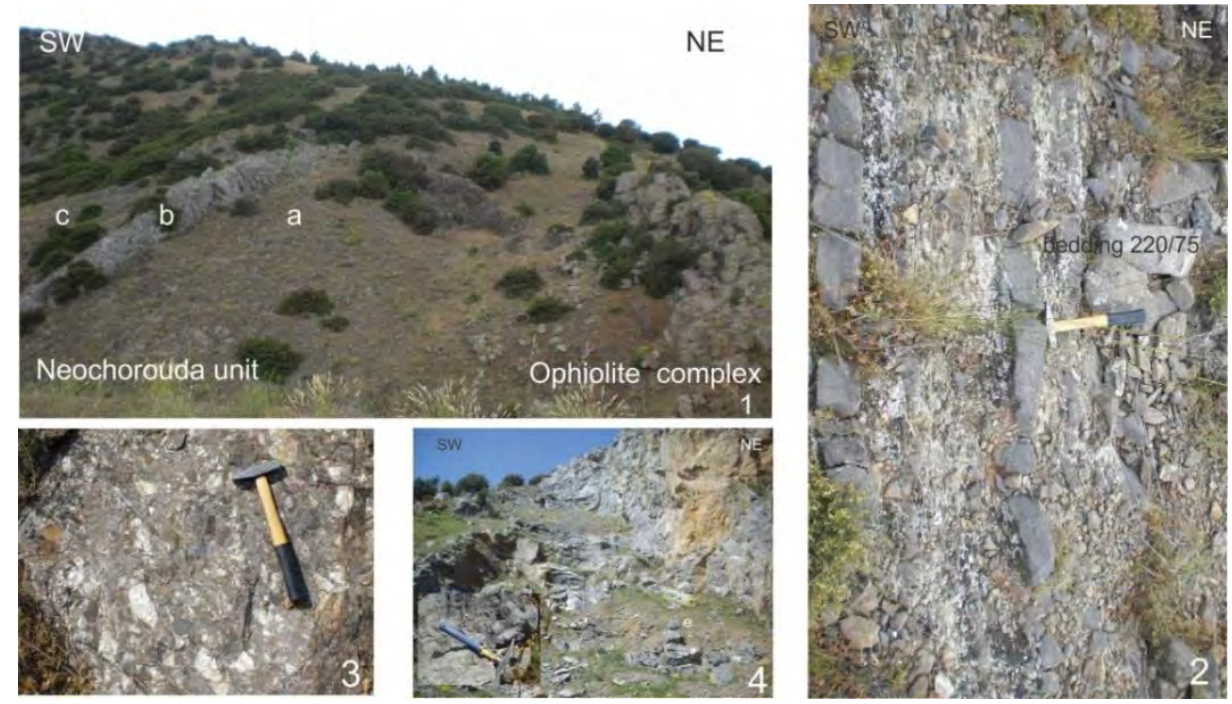

Figures 3 - 1 Neochorouda Unit overlying the Oreokastro ophiolite complex of the Vardar/Axios zone. The letters a, b, $c$ indicates the samples locations for the biostratigraphic analysis. 2 The turbiditic sandstone sequence and sampling point c. 3 Conglomerate with different clasts. Sampling point d. 4 Shallow-water carbonates. Sampling point e.
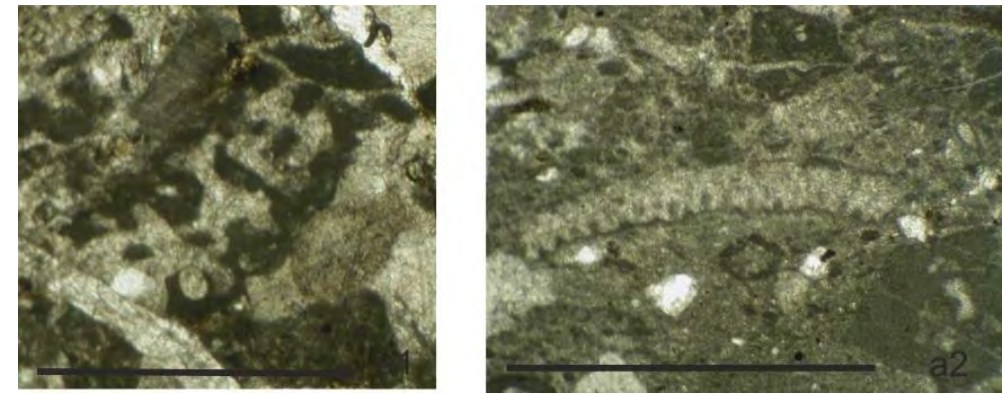

Figure 4 - Microfossils from shallow-water carbonate clasts inside the breccia from Neochorouda Unit. a1. Labyrinthina mirabilis, a2. Griphoporella jurassica.

\subsection{Reconstruction of the Jurassic to Early Cretaceous tectonic evolution}

Specifically interesting are the coarse-grained breccias with mixed ophiolite material and shallowwater carbonate clasts below the early Berriasian turbidites. The clasts derive from fore-reef, reef, back-reef and open lagoonal areas containing different microencruster associations, stromatoporoids, sponges, corals and also Neoteutloporella socialis (Praturlon), Perturbatacrusta leini Schlagintweit \& Gawlick. Common microencrusters include Radiomura cautica SenowbariDaryan \& Schäfer, Crescentiella morronensis (Crescenti) and Labes atramentosa Eliasova (Figure 5). We interpret these clasts as erosional products of a ?Kimmeridgian-Tithonian carbonate platform which was formed on top of the ophiolites.

Age dating of the whole sequence including component analysis and detection of an eroded Late Jurassic platform led to following reconstruction of the geodynamic evolution: 
The closure of the western part of the Neotethys Ocean in late Early to Middle Jurassic was triggered by intra-oceanic subduction. This convergence east of the "Pelagonia continent" resulted in west-directed late Middle to early Late Jurassic ophiolite obduction and WNW to NW directed nappe stacking of the sediment cover units of "Pelagonia" in the western Vardar/Axios (= Neotethys) Ocean (Kilias et al., 2010). Ophiolite obduction onto the Pelagonian Units and imbrication of the Pelagonian sedimentary sequence are related to the same thrusting process. This process was followed by the onset of a shallow-water platform on top of the nappe stack. This Late Jurassic carbonate platform evolution on top of the Middle to Late Jurassic nappe stack can be traced from the Eastern Alps to the Hellenides (Gawlick et al., 2008; Schlagintweit et al., 2008; Missoni et al., 2011). The new biostratigraphic and microfacies analysis of the clasts in the mass flows at Neochorouda Unit provides us new information about this platform pattern, which was eroded in the study area around the Jurassic/Cretaceous boundary.

Late Tithonian to Early Cretaceous extension and updoming of the nappe stack including the obducted ophiolites due to mountain uplift resulted in a reconfiguration of the nappe stack and newly formed basins west and east of the Pelagonian Units. Late Tithonian to earliest Cretaceous erosion of the uplifted nappe stack including the obducted ophiolites resulted in sediment supply into these basins. Erosion of the Late Jurassic carbonate platform together with ophiolite material and later the occurrence of metamorphic Triassic clasts clearly prove updoming of the nappe pile, crustal extension and gravitational sliding of the nappe pile to the west and to the east, as it can be demonstrated by identical successions on both sides of the Pelagonian Units in Greece (this paper, Dragastan \& Richter, 2003), Albania (Schlagintweit \& Gawlick, 2007, Schlagintweit et al., 2008) and Serbia (Radoicic, 1982). First the topmost nappes including their sedimentary cover (ophiolites and Late Jurassic platform sediments) became eroded (around the Jurassic/Cretaceous boundary - Berriasian). Later, but still in the earliest Cretaceous (Berriasian) the metamorphosed Triassic-Jurassic Pelagonian sedimentary rocks started to erode: The thick conglomerates with the metamorphic carbonate clasts of Pelagonian derivation were deposited, maybe in the course of a sea-level drop.
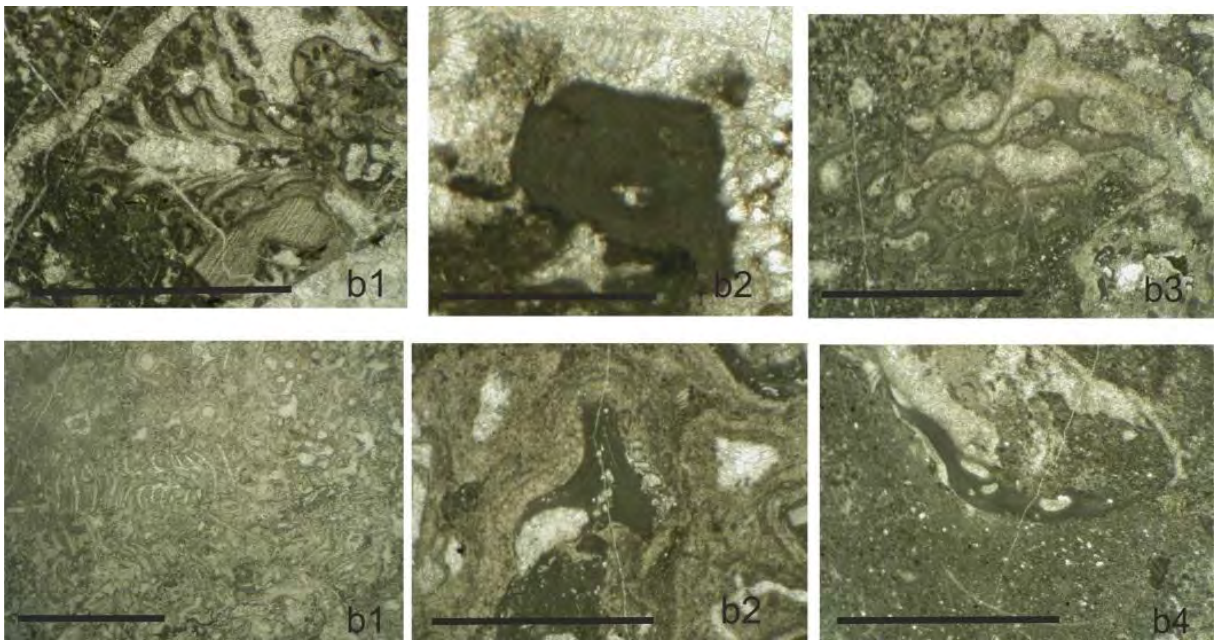

Figure 5 - Microfossils from shallow-water clasts inside the coarse-grained breccia from Neochorouda Unit. b1. Neoteutloporella socialis, b2. Crescentiella morronensis, b3. Pertubatacrusta leini, b4. Labes atramentosa.

In the study area the first erosional stages can be proven by the existence of the Berriasian turbiditic sequence of immature sandstones with coarse-grained mass flows below and intercalated (Figure 3.2). The carbonate clasts contain Dissocladella? bakalovae, Anchispirocyclina lusitanica (Egger), Pseudocyclammina lituus (Yokoyama), L. atramentosa Eliasova (Figure 6). In the next stage due to the exhumation of the metamorphic dome (Berriasian) deep erosion led to the 
formation of the polymictic conglomerate of the Neochorouda succession (Figure 3.3) with e.g. quartzite, metamorphic radiolarites, and different metamorphosed shallow-water clasts of most probably late Middle Triassic age (Figure 7).

This earliest Cretaceous succession was again sealed by a newly formed ?Late BerriasianValanginian shallow-water platform most probably in the course of the next sea-level rise resp. highstand. The latter is represented in Neochorouda area by the shallow-water carbonates (Figure 3.4) with C. morronensis (Crescenti), Suppiluliumaella aff. methana Dragastan \& Richter, Carpathoporella sp., Coscinophragma sp., Selliporella neocomiensis (Radoicic), Andersenolina sp., Solenoporaceae, Linoporella aff. capriotica (Oppenheim), Griphoporella cretacea (Dragastan), Furcoporella? vasilijesimici Radoicic (Figure 8).
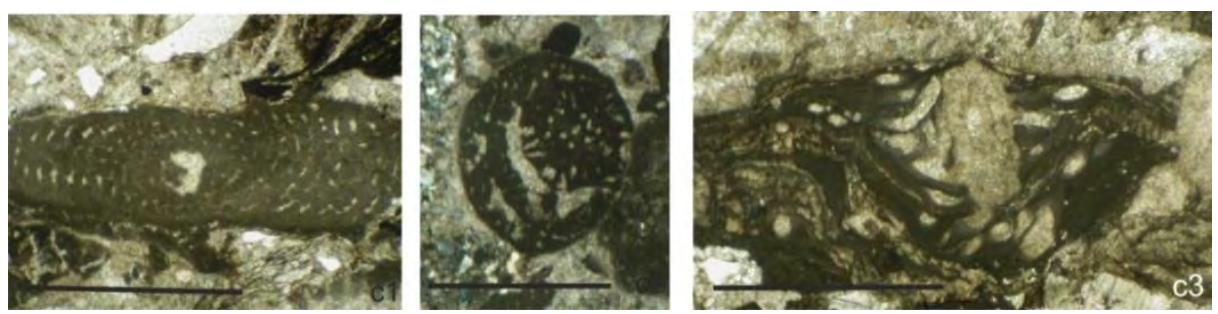

Figure 6 - Microfossils from the carbonate clasts inside the turbiditic sequence from Neochorouda Unit. c1. Anchispirocyclina lusitanica, c2. Pseudocyclammina lituus, c3. Labes atramentosa.

Plate convergence and westwards thrusting continued during Aptian to Albian times. N-S trending overturned isoclinal folds with vergence towards west and an impressive eastwards dipping S2 foliation parallel to the folds axis plane was developed during that time (Figure 9). Upper Cretaceous limestones and Palaeocene flysch sediments overlay unconformably these tectonics structures and the Late Jurassic to Early Cretaceous sedimentary succession. After that the Neochorouda Unit has been affected by the younger Tertiary tectonics including compression and nappe stacking, followed by extension and again an orogenic collapse.
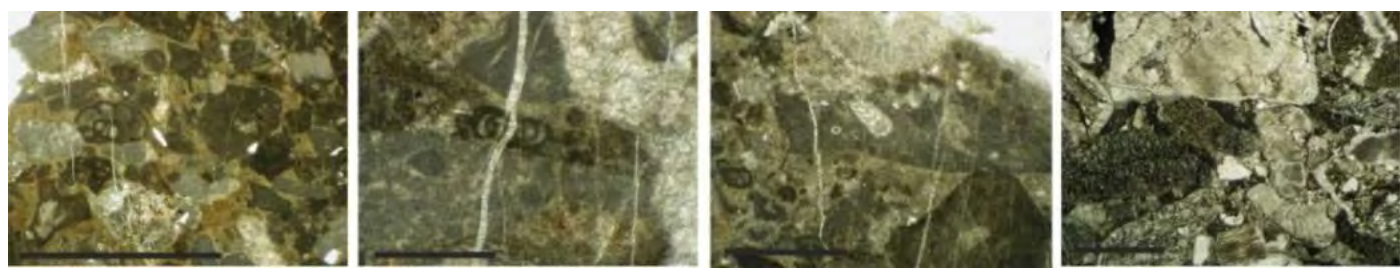

Figure 7 - Conglomerate with different clasts from the Neochorouda Unit, e.g. quartzite's resp. metamorphic radiolarites, different metamorphosed shallow-water clasts of most probably Middle Triassic age and carbonate clasts containing foraminifera.

Microfacies and organism content at Neochorouda Unit resembles the Late Jurassic carbonate platforms formed on top of the Middle to Late Jurassic nappe stack striking from the Eastern Alps to the Hellenides. In detail, an equivalent sequence of shallow-water limestones and clastic sediments is recognized further to the west in Albania, where it seals the Mirdita ophiolitic nappe stack (Gawlick et al., 2008). The same scenario with ophiolite obduction in Middle-Late Jurassic followed by formation of shallow-water platforms, extensional collapse due to tectonic thickening and mountain uplift before the Jurassic/Cretaceous boundary, and infilling of the foreland basins with the erosional products of the orogeny in Early Cretaceous has also been described in the Eastern Alps (Missoni \& Gawlick, 2011). Additionally, west of the Pelagonian Units occurs the carbonate sequence of Acrocorinth and of the Perachora peninsula, which has been interpreted as lagoonal facies areas of a Late Jurassic to Early Cretaceous carbonate platform (Dragastan \& Richter, 2003). 


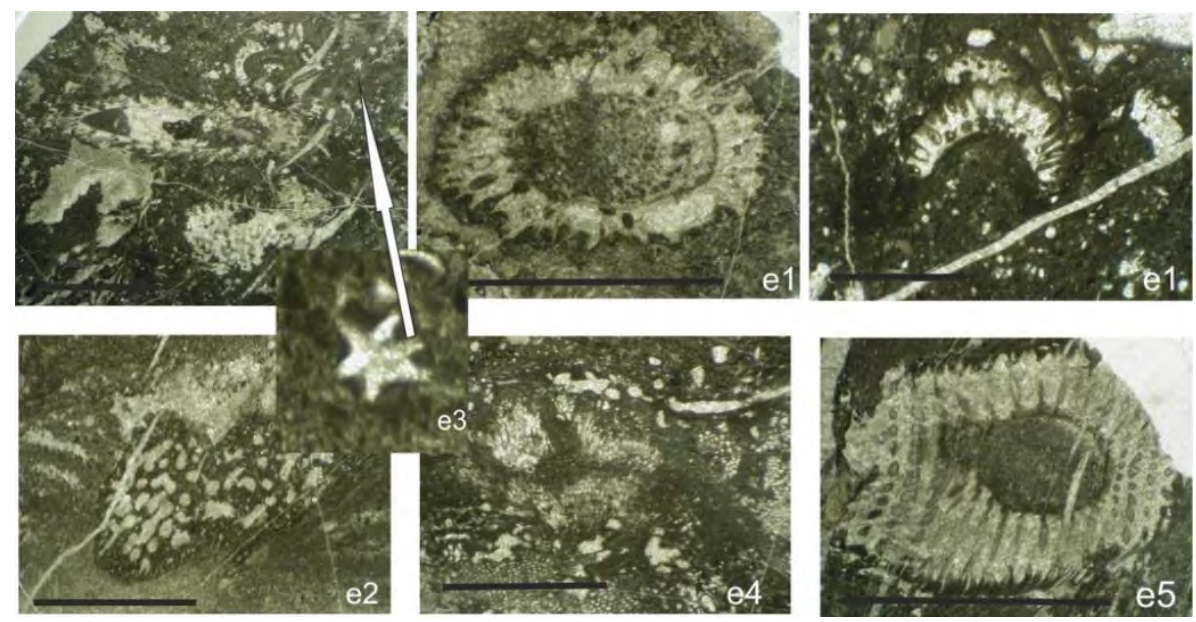

Figure 8 - Microfossils from shallow-water carbonates from the Neochorouda Unit. e1. Suppiluliumaella aff. methana, e2. Coscinophragma sp., e3 debris of tufts of secondary laterals of Selliporella neocomiensis, e4. Solenoporaceae, e5. Linoporella aff. capriotica.
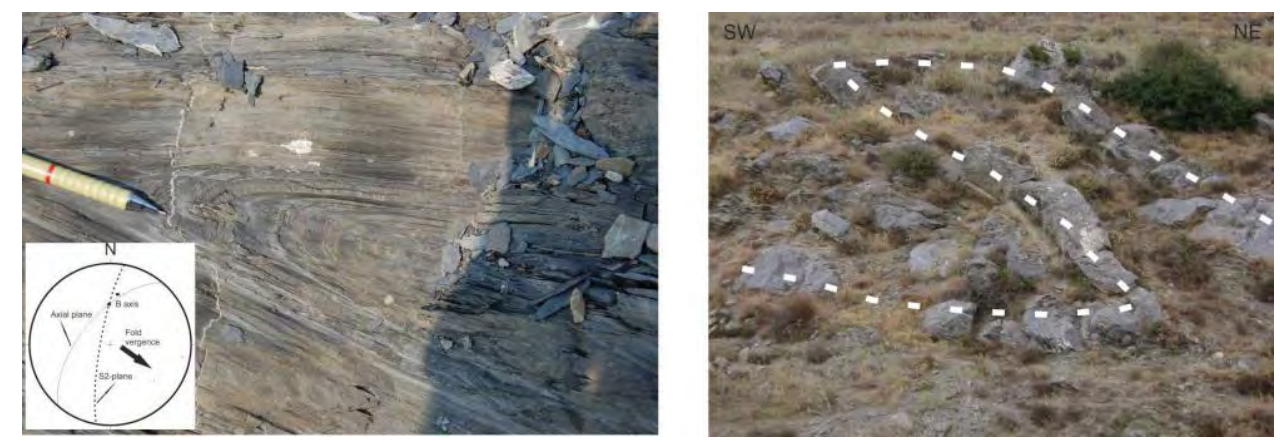

Figure 9 - Isoclinals folds of Early Cretaceous with S2 foliation. Schmidt diagram of the geometrical data of the fold (Lower hemisphere).

\section{Discussion and Conclusions}

The Late Jurassic to Early Cretaceous sedimentary succession of the Neochorouda Unit lies unconformably on top of the Oreokastro ophiolites of the Vardar-Axios "suture zone" in Northern Greece. This succession consists of mass flows and provides an upper limit for ophiolite emplacement. New biostratigraphic and microfacies analysis of the clasts in the mass flows were carried out for a better understanding of the Late Jurassic to Early Cretaceous evolution and provide new information about the derivation of the ophiolite complex.

- Middle to Late Jurassic nappe stacking towards WNW to NW was related to intra-oceanic thrusting in the western Vardar/Axios (=Neotethys) Ocean and subsequent ophiolite obduction onto the Pelagonian Units. After ophiolite emplacement KimmeridgianTithonian carbonate platforms sealed widespread this tectonic event.

- Tithonian extension due to mountain uplift resulted in partial erosion of these platforms including the ophiolites and new basins were formed. Later the metamorphosed Triassic carbonates became eroded and re-deposited. The erosional products of the Neochorouda Unit in the Vardar/Axios zone resemble the erosional products known west of the Pelagonian units, e.g. in Albania or Serbia and should derive therefore from the same palaeogeographic provenance area. 
- Late Tithonian to earliest Cretaceous erosion of the uplifted nappe stack including the obducted ophiolites resulted in sediment supply into the newly formed basins east and west of the Pelagonian Units. The coarse-grained succession was sealed by a newly formed ?Late Berriasian-Valanginian shallow-water platform, also known west of the Pelagonian units.

This paper contributes to previous works at least since Kober (1914) proposing that in Triassic to Early Cretaceous times the area from the Eastern Alps in the north to the Hellenides in the south underwent the same geodynamic history (see also Kossmat, 1924). Formation of the Neotethys oceanic crust since Late Anisian, onset of intra-oceanic thrusting in the Jurassic, westward ophiolite obduction and formation of the nappe pile on the lower plate from late Middle Jurassic times onward followed by the formation of Kimmeridgian-Tithonian shallow-water platforms, a latest Jurassic extensional collapse due to tectonic thickening and mountain uplift around the Jurassic/Cretaceous boundary, and infilling of the foreland basins with the erosional products of this orogeny in Early Cretaceous as known from the Eastern Alps/West Carpathians, the Southern Alps, Dinarides, and Albanides (e.g., Gawlick et al., 2008; Schlagintweit et al., 2008; Missoni et al., 2011).

\section{Acknowledgments}

This study comes as a sequence of work that took place at Leoben University through the European Community Action Scheme for the Mobility of University Students program. Use of the laboratory facilities of the Department of Applied Geosciences and Geophysics, Chair of Petroleum Geology at the University of Leoben are gratefully acknowledged. Special thanks go to Sigrid Missoni for her helpful assistance during the laboratory work.

\section{References}

Bebien J., Dubois R. and Gauthier A. 1986. Example of ensialic ophiolites emplaced in wrench zone: innermost Hellenic ophiolite belt (Greek Macedonia), Geology, 14, 1016-1019.

Brown S.A.M. and Robertson A.H.F., 2004. Evidence for the Neotethys ocean rooted in the Vardar zone: evidence from the Voras Mountains, NW Greece, Tectonophysics, 381, 143173.

Channell J.E.T. and Kozur H.W. 1997. How many oceans? Meliata, Vardar and Pindos oceans in the Mesozoic Alpine paleogeography, Geology, 25, 183-186.

Dimitriadis S. and Asvesta A. 1993. Sedimentation and magmatism related to the Triassic rifting and later events in the Vardar-Axios Zone, Bull. Geol. Soc. Greece, 28, 149-168.

Dragastan O. and Richter D.K. 2003. Late Jurassic oolites from the Acrocorinth (NEPeloponnesus): Calcareous-micro-algae as an exceptional paleoecologic indicator, Bochumer geologische und geotechnische Arbeiten, 53, 149-172.

Gawlick H.J., Frisch W., Hoxha L., Dumitrica P., Krystyn L., Lein R., Missoni S. and Schlagintweit F. 2008. Mirdita zone ophiolites and associated sediments in Albania reveal Neotethys Ocean origin, Int. J. Earth Sci., 94, 865-881.

Kilias A., Frisch W., Avgerinas A., Dunkl I., Falalakis G. and Gawlick H.J. 2010. Alpine architecture and kinematics of deformation of the northern pelagonian nappe pile in the Hellenides, Austrian Journal of Earth Sciences, 103/1, 4-28.

Kober L. 1914. Die Bewegungsrichtung der alpinen Deckengebirge des Mittelmeeres, Geographische Mitteilungen, 60, 250-256, Petermanns.

Kockel F. and Mollat, H. 1977. Geological map of the Chalkidiki peninsula and adjacent areas (Greece), Scale 1:100000, Bundesanstalt fur Geowissenschaften und Rohstoffe, Hannover.

Kossmat F. 1924. Die Kriegsschauplatze 1914-1918 geologisch dargestellt. Heft 12: Geologie der zentralen Balkanhalbinsel. Mit einer Übersicht des dinarischen Gebirgsbaus, (Borntraeger) $198 \mathrm{pp}$. 
Meinhold G., Kostopoulos D., Reischmann T., Frei D. and BouDagher-Fadel M.K. 2009. Geochemistry, provenance and stratigraphic age of metasedimentary rocks from the eastern Vardar suture zone, northern Greece, Palaeogeography Palaeoclimatology Palaeoecology, 277, 199-225.

Mercier J. 1968. Etude geologique des zones internes hellenides en Macedoine centrale (Grece). Contribution a 1 etude du metamorphisme et de 1 evolution magmatique des zones internes des Hellenides, Annales geologiques des pays helleniques, 20, 1-792.

Missoni S. and Gawlick H.J. 2011. Evidence for Jurassic subduction from the Northern Calcareous Alps (Berchtesgaden; Austroalpine, Germany), Int. J. Earth Sci., 100, 1605-1631.

Mussallam K. and Jung D. 1986. Geology und Bau des Sithonia-Ophioliths (Chalkidiki, NE Griechenland: Anmerkungen zur Bildung ozeanischer Krusten), Geologische Rundschau, 75, 383-409.

Radoicic R. 1982. Carbonate platforms of the Dinarides: The example of Montenegro-West Serbia Sector, Bulletin de l'Académie Serbe des sciences et des arts, Classe des sciences naturelles et mathematiques, 22, 35-46.

Ricou L.E., Burg J.P., Godfriaux I. and Ivanov Z. 1998. Rhodope and Vardar: the metamorphic and the olitostromic paired belts related to the Cretaceous subduction under Europe, Geodinamica Acta, 11, 285-309.

Robertson A.H.F. 2012. Late Palaeozoic-Cenozoic tectonic development of Greece and Albania in context of alternative reconstructions of Tethys in the Eastern Mediterranean region, International Geology Review, 54, 373-454.

Robertson A.H.F., Trivic B., Djeric N. and Bucur I.I. 2012. Tectonic development of the Vardar ocean and its margins: Evidence from the Republic of Macedonia and Greek Macedonia, Tectonophysics, Available online at: http://dx.doi.org/10.1016/j.tecto.2012.07.022

Roddick J., Cameron W. and Smith A.G. 1979. Permotriassic and Jurassic Ar/Ar ages from Greek ophiolites and associated rocks, Nature, 279, 788-790.

Schlagintweit F. and Gawlick H.J. 2007. Analysis of the Late to Early Cretaceous algal debrisfacies of the Plassen carbonate platform in the Northern Calcareous Alps (Germany, Austria) and in the Kurbnesh area of the Mirdita zone (Albania) - a tool to reconstruct tectonics and paleogeography of eroded platforms, Facies, 53, 209-227.

Schlagintweit F., Gawlick H.J., Missoni S., Hoxha L., Lein R. and Frisch W. 2008. The eroded Late Jurassic Kurbnesh carbonate platform in the Mirdita ophiolite Zone of Albania and its bearing on the Jurassic orogeny of the Neotethys realm, Swiss Journal of Geosciences, 101, 125-138.

Schmid S.M., Bernoulli D., Fugenschuh B., Matenco L., Scheffer S., Schuster R., Tischler M. and Ustaszewski k. 2008. The Alps-Carpathians-Dinarides connection: a correlation of tectonic units, Swiss Journal of Geosciences, 101 (1), 139-183.

Smith A.G. and Spray J.G., 1984. A half-ridge transform model for the Hellenic-Dinaric ophiolites. in: Dixon, J.E. \& Robertson, A.H.F. (eds), The Geological evolution of the Eastern Mediterranean, Geological Society of London, Special Publications, 17, 629-644.

Stampfli G.M., 2000. Tethyan oceans. In: Tectonics and magmatism in Turkey and the Surrounding Area, Geological Society of London, Special Publications, 173, 1-23.

Vergely P. and Mercier, J. 2000. Données nouvelles sur les chevauchements d'âge post-Crétacé supérieur dans le massif du Païkon (zone de l'Axios-Vardar, Macédoine, Grèce): un nouveau modèle structural, Comptes Rendus de l'Académie des Sciences de Paris, 330, 555-561.

Zachariadis P. 2007. Ophiolites of the eastern Vardar Zone, N. Greece, PhD Thesis, University of Mainz, Germany. 